\title{
Traumatic Middle Cerebral Artery Occlusion: A Case Report
}

\section{Travmatik Orta Serebral Arterin Tikanması: Olgu Sunumu}

\author{
๑ Aykut Akpınar, ๑ Uzay Erdoğan*, ๑ Ergün Karavelioğlu**, ๑ Bekir Mahmut Kılınç \\ University of Health Sciences, Haseki Training and Research Hospital, Clinic of Neurosurgery, Istanbul, Turkey \\ *istanbul Bakırköy Dr. Mazhar Osman Mental Health and Neurological Diseases Training and Research Hospital, Clinic of Neurosurgery, \\ istanbul, Turkey \\ **Afyon Kocatepe University, Clinic of Neurosurgery, Afyon, Turkey
}

\begin{abstract}
Traumatic occlusion of the middle cerebral artery (MCA) is a rare cause of cerebral infarction. Malignant infarction of the MCA is associated with a mortality rate of $80 \%$. Arterial dissection, cerebral vasospasm, and thrombosis may be the pathogenesis of this condition. Poor admission Glasgow coma scale score, low systolic blood pressure, and brain herniation are significantly associated with development of posttraumatic cerebral infarction. There is no effective medical treatment for malignant MCA infarction. Decompressive craniotomy is the last solution to prevent severe damage or death. We report a 51-year-old female having craniofacial injury, multiple chest trauma, hemothorax, pneumothorax, and cerebral infarction after a traffic accident. Despite decompression surgery, she died two days after the injury.
\end{abstract}

Keywords: Middle cerebral artery, trauma, decompressive craniectomy, posttraumatic cerebral infarction
Öz

Orta serebral arterin (OSA) travmatik kapanması serebral damar tıkanıklığının nadir sebebidir. Malign OSA damar tıkanıklıkları \%80 mortalite oranı ile ilişkilidir. Arter duvarının yırtılması, serebral damar spazmı ve trombozis bu durumun patogenezinde rol oynuyor olablir. Glasgow koma skorunun düşük olması, düşük sistolik kan basıncı ve beyin herniasyonunun travma sonrası serebral damar tıkanıkıgı gelişmesi ile manidar ilişkisi vardır. Malign OSA damar tıkanıklı̆ının etkili bir medikal tedavisi yoktur. Dekompresif kraniyotomi devam eden hasar veya ölümden korunmada son çözüm yoludur. Biz, trafik kazası sonrası yüz ve kafa travması, çoklu gögüs travması, hemotoraks, pnömotoraks ve serebral damar tıkanıklığı olan 51 yaşında bayan hastayı sunduk. Dekompresif cerrahiye rağmen hastamı travma sonrası iki gün sonra kaybedilmiştir.

Anahtar Sözcükler: Orta serebral arter, travma, dekompresif kraniektomi, travma sonrası serebral damar tıkanıklığı

PTCI risk factors are lower Glasgow coma scale (GCS) score, hypotension and higher intracranial pressure (ICP). Early identification of patients who are at a particular risk for PTCl would be extremely helpful in surgery. Early decompressive surgery (DC) confers a survival benefit $(2,4,6)$.

Cerebral vasopasm, vascular injury, and hypoperfusion may cause PTCl. $(1,3,4)$. Traumatic brain injury pathophysiology includes brain swelling, increased ICP, reduction in blood and oxygen supply, energy failure, and cell death (4). Thrombus formation is unclear. Acceleration,
Address for Correspondence/Yazışma Adresi: Aykut Akpınar

University of Health Sciences, Haseki Training and Research Hospital, Clinic of Neurosurgery, İstanbul, Turkey Phone: +90 5336109583 E-mail: aykut1953@yahoo.com ORCID ID: orcid.org/ 0000-0002-5049-3259

Received/Geliş Tarihi: 19 February 2018 Accepted/Kabul Tarihi: 05 March 2018
${ }^{1}$ Copyright 2018 by The Medical Bulletin of University of Health Sciences Haseki Training and Research Hospital

The Medical Bulletin of Haseki published by Galenos Yayınevi.

'Telif Hakkı 2018 Sağlık Bilimleri Üniversitesi Haseki Eğitim ve Araşıırma Hastanesi Haseki Tıp Bülteni, Galenos Yayınevi tarafından basılmışıır. 
deceleration, or rotational motions between the brain, skull, and neck may cause vascular injury (7).

First of all, the patients should be checked out about cardiac, vascular and blood diseases (8).

After severe traumatic brain injury, in order to control brain swelling, either medical or surgical therapies should be used. ICP should be lower than 20-25 mmHg. Simple therapeutic maneuvers, including sedation, ventilation, and head-up position, should be done as the first step. After these, more advanced medical treatment, including application of inotropes, hypertonic saline, mannitol, and hypothermia can be performed. External ventricular drainage of the cerebrospinal fluid can be useful. If these modalities fail to control ICP, we need more advanced therapy, especially barbiturate coma therapy or DC $(5,9$ 11).

DC (removal of a part of the skull and duraplasty) is a good way to accommodate shifts of brain tissue and normalize ICP. DC is a radical and fast way of solution for the management of brain tissue shift and ICP. Surgical decompression reduces death rate and improves the functional outcome of patients. DC is mostly used as the last solution to prevent severe damage or death. In MCA infarction, DC reduces mortality by nearly $52.8 \%$, but there is no consensus on if and when to proceed to surgery. DC may save one's life at the expense of creating a vegetative state and severe disability $(10,12)$.

Computed tomography (CT) is useful in the detection of various cerebral pathologies, including infarction. Magnetic resonance imaging (MRI), MR angiography, $\mathrm{CT}$ angiography, and $\mathrm{CT}$ perfusion can be used for the diagnosis of cerebral infarction $(2,13)$.

\section{Case}

A 51-year-old female was admitted to our emergency department with multiple trauma after a traffic accident. On presentation to the emergency department, she became confused, disoriented, and combative. She was noted to have left-sided hemiparesis and facial paralysis and was not obeying commands. Her systolic blood pressure was low (80 $\mathrm{mmHg}$ ). After admitting emergency department, maintain the hemodynamic balance, preventing hypotension, hypoxia, elevation of the head by $20^{\circ}$ to $30^{\circ}$, hyperosmolar therapy with mannitol or hypertonic saline treatments were started. On CT images, maxillofacial fractures, multiple rib fractures, hemothorax, and pneumothorax were seen. A chest tube was inserted urgently. After admission, the patient was taken to the intensive care unit. After three hours, the patient's GCS score was 6, and she had anisocoria but did not lose pupillary reaction to light. She had irregular breathing and pulse and underwent mechanical ventilation with controlled hyperventilation and sedation (using propofol and fentanyl). CT scans revealed right-sided hypodensity, MCA infarction and midline shift (Figures 1-3). Despite the conservative medical therapy, the ICP was over $25 \mathrm{mmHg}$. We could not take cerebral angiography or MRI, be cause of her poor general condition.

Except for the international normalized ratio (INR), other blood tests were normal, and she did not require an anticoagulant therapy, but her INR was 6. Fresh frozen plasma was given to the patient in order to reduce the INR. High-dose steroid treatment was given on the day of admission, and after 12 hours, the INR was normalized. After obtaining written informed consent from her family, operation was performed.
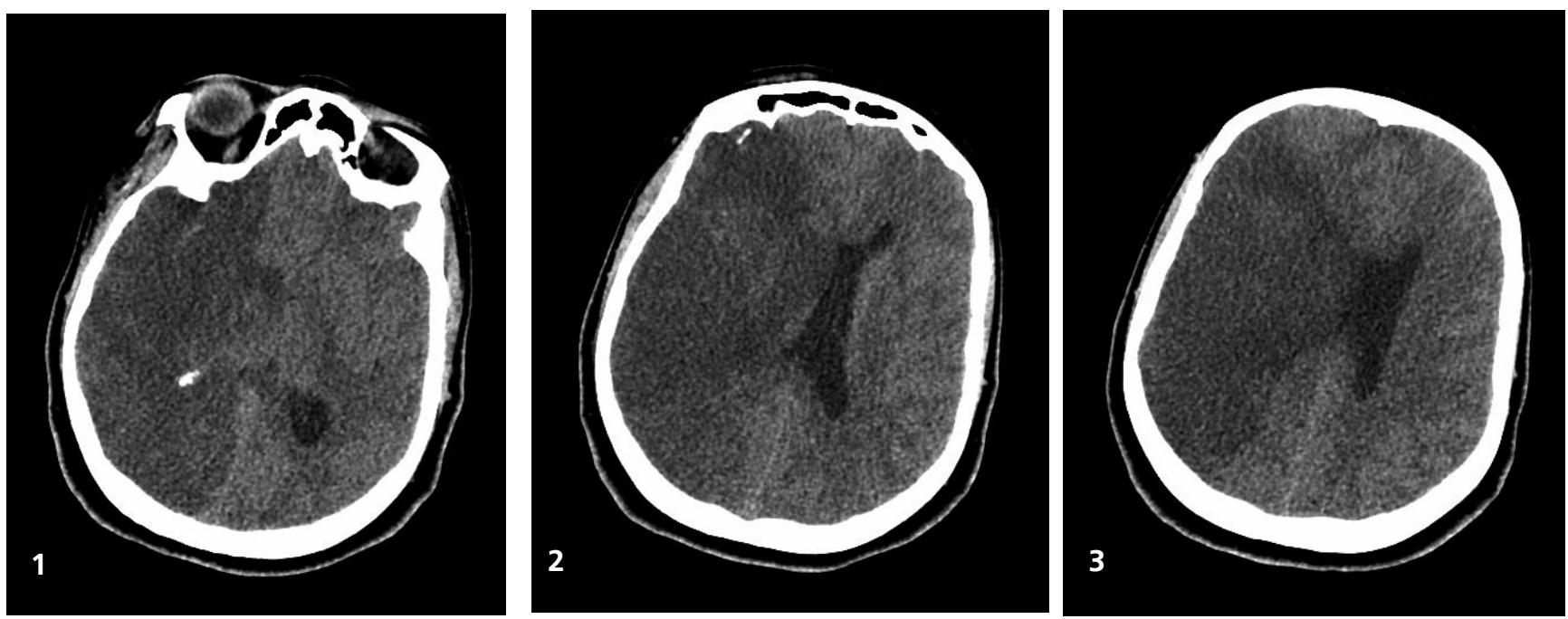

Figures 1-3. Preoperative computed tomography scans show the hypodense infarction area and midline shift effect 


\section{Surgery}

DC consisted of a duraplasty and the creation of a large bone flap. Removal of head bone and enlargement of dura with duraplasty is DC's mainstays. In summary, a large skin incision in the shape of a question mark based at the ear is made. Frontotemporal question mark skin incision was made. A frontotemporoparietal bone flap was removed. The dura was opened, and a fascia lata graft was used for duraplasty. Dural tenting sutures were used in order to stop epidural hemorrhage. The temporal muscle and skin flap were then reapproximated and sutured.

After surgery, the patient was transferred to the intensive care unit. We did not use sedation or muscle relaxants. Her GCS score was 3 after the day of injury. A control CT scan revealed right-sided malignant MCA infarction and decreased midline shift (Figures 4-6). She died on the third day of her admission to the hospital.

\section{Discussion}

Due to high mortality and mortality rate, PTCI is destructive complication of trauma $(1,2,14)$. Overall mortality rate is $75 \%$. A GCS score between 3 to 5 is a high risk factor for mortality. Traumatic herniation of the brain may cause malignant high ICP which causes brain death. Despite modern medicine, CT scans, drugs, intensive care and monitoring, PTCl's mortality and morbidity rate is still high (2).

Low GCS (3-8), hypotension, and head trauma with vascular damage are main risk factors for brain shift and herniation with occurrence of fatal brain edema $(2,4)$. The radiological factors for midline shift and postsurgical affected-to-contralateral side ratio are important clues of predicting clinical outcomes (15-18).

Regarding neurological status, the GCS score at admission and prior to surgery was 8 and 6 , respectively. In addition, there was hypotension $(60 \mathrm{mmHg}-30 \mathrm{mmHg}$ ).
On $\mathrm{CT}$, it was observed that the midline shift was $10 \mathrm{~mm}$. The time interval between injury and surgery was 12 hours. Hypotension is lustily associated with cerebral infarctions. Primarily, head trauma is complicated with craniofacial and limb fracture, chest trauma, and hemothorax.

Hypotension and hypoxia are significant predictors of mortality (4). If arterial perfusion is limitted with direct effect over cerebral cortex, infarction may occur. Intracranial vasospasm is also likely to occur in patients with severe injury (8). Rotational forces following trauma are secondary to the arterial wall intimal dissection, with primary thrombosis and vasospasm as less likely causes (1). Spasm may be due to direct vascular trauma or the effect of adjacent contusion and hemorrhage or may be mediated by release of a vasoactive humoral factor (6). The reported incidence of intracranial arterial spasm following moderate to severe head injury is in the range of $5 \%$ to $10 \%(1,19)$.

Massive hemispheric infarctions cause poor clinical outcome. If not treated surgically, case fatality is $80 \%$ (5). In several studies, there was a dramatic effect of surgery, with a highly significant absolute reduction of $52.8 \%$ in the death rate in the surgery group compared with the no-surgery group $(9,10,15,20)$.

Anticoagulation using orally-administered lowmolecular-weight heparin and thrombolysis using a recombinant tissue plasminogen activator have been found to be effective in adult patients when given within three hours of the thrombotic event. We could not use heparin and acetylsalicylic acid therapy because of high INR. Head trauma may cause coagulation abnormalities with poor clinical outcome. Elevated admission INR, elevated INR at 24 hours, and overall trend in INR strongly predict mortality in the trauma population $(22,23)$. After giving the patient frozen plasma and vitamin $\mathrm{K}$ and, decreasing the level of INR, DC operation was started.
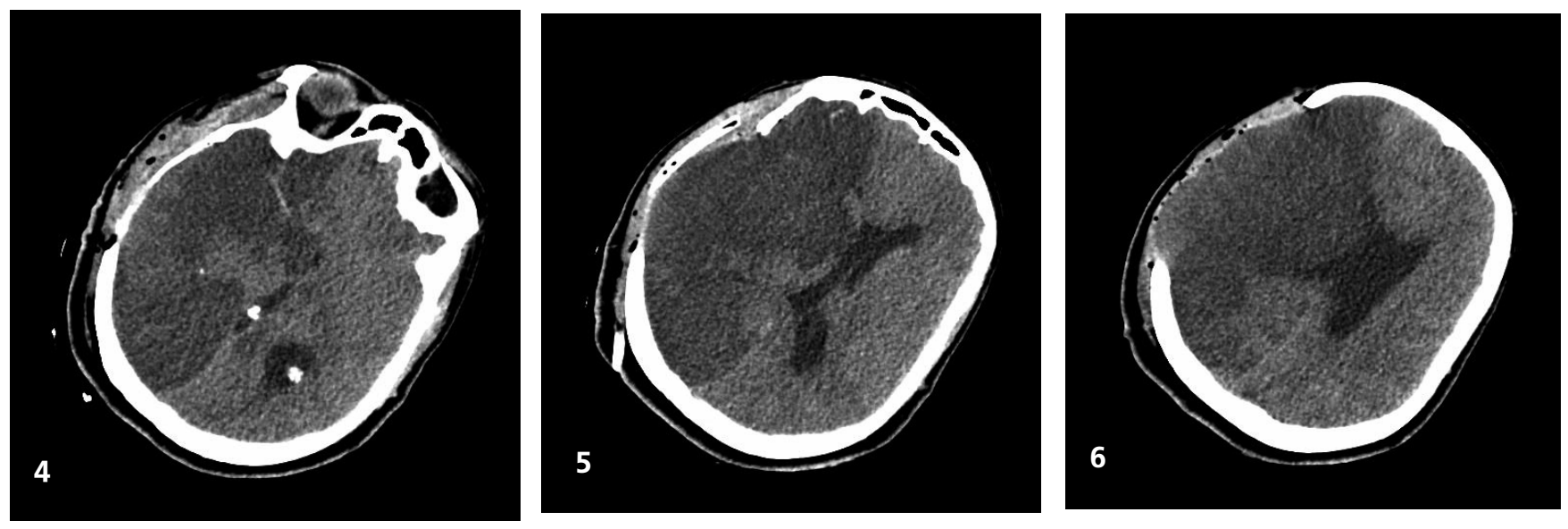

Figures 4-6. Postoperative computed tomography scans show the infarction area and still the midline shift 
Unless medical treatments are succesful, DC is an established modality. Fastest way in order to reduce $I C P$, early DC and duraplasty are needed $(2,12,14,21)$. In patients with a GCS less than 5, the risk of mortality increases. At this point, irreversible ischemic damage has no chance of recovery $(2,15)$.

In the presence of bilaterally fixed or dilated pupils, a GSC of 3 or haemorrhagic transformation of the infarct, known coagulopathy or systemic bleeding disorder, contraindication for anesthesia, pregnancy, or contralateral ischemia, surgery should be avoided (5).

Death from brain herniation is not the only outcome. After a cerebral infarction, prolonged intensive care is needed, and worse outcomes, such as pneumonia, venous thromboembolic complications, seizures, depression, urinary tract infection, cerebral abscess, tracheostomy, gastric ulcer, etc., may occur (10).

Early diagnosis and successful management of traumatic cerebral infarction require a high degree of clinical suspicion. Close monitoring of the patient's neurologic condition is necessary for early diagnosis and succesful management of PTCl The decision about whether to perform DC or not is based on the patient's age, medical history, laboratory findings, neurological condition (GCS, clinical examination), imaging (CT or MRI) findings, in case of failure of conservative treatment and clinical deterioration. According to the literature, in the first 12 to 48 hours, early DC confers a survival benefit.

If $\mathrm{PTCl}$ occurs earlier with poor clinical status, this may cause high mortality and morbidity. Delayed surgery may cause irreversible ischemic infarcts. Even though we used medical and surgical treatment, the patient died. Malignant MCA infarction treatment is so difficult. In our patient, the presence of multiple trauma, including chest trauma, hemothorax, pneumothorax, craniofacial, and limb fractures, coagulation problems, and hypotension made it more difficult.

Decompressive craniectomy is widely accepted and applied as a rescue therapy in patients with refractory elevated ICP. DC provides the fastest relief by immediate reduction in raised ICP and resolution of midline shift.

\section{Authorship Contributions}

Design: A.A., U.E. Data Collection or Processing: A.A., U.E. Analysis or Interpretation: A.A., E.K., U.E., B.M.K. Literature Search: A.A., E.K. Writing: A.A., E.K., B.M.K.

Conflict of Interest: No conflict of interest was declared by the authors.

Financial Disclosure: The authors declared that this study received no financial support.

\section{References}

1. Mobs RJ, Chandran KN. Traumatic middle cerebral artery occlusion: case report and review of pathogenesis. Neurology India 2001;49:158-61.

2. Ham HY, Lee JK, Jang JW, et al. Post-Traumatic Cerebral Infarction: Outcome after Decompressive Hemicraniectomy for the Treatment of Traumatic Brain Injury. J Korean Neurosurg Soc 2011;50:370-6.

3. Server A, Dullerud R, Haakonsen M, Naksted PH, Johnsen UL, Magnaes B. Post-traumatic cerebral infarction. Neuroimaging findings, etiology and outcome. Acta Radiol 2001;42:254-60.

4. Tawil I, Stein DM, Mirvis SE, Scalea TM. Posttraumatic cerebral infarction: incidence, outcome, and risk factors. J Trauma 2008;64:849-53.

5. Vahedi K, Hofmeijer J, Juettler E, et al. Early decompressive surgery in malignant infarction of the middle cerebral artery: a pooled analysis of three randomised controlled trials. Neurology 2007;6:215-22.

6. Tian H-L, Geng Z, Cui Y-H, Xu T, et al. Risk factors for postraumatic cerebral infarction inpatients with moderate or severe head trauma. Neurosurg 2008;31:431-7.

7. Chiba F, Makino Y, Motomura A, et al. Bilateral middle cerebral artery infraction associated with traumatic common carotid artery dissection: A case report and review of literature. Forensic Science International 2014;236:e1-e4.

8. Gumus $\mathrm{H}$, Coskun A, Per H. Traumatic medial cerebral artery occlusion in a 4-year-old child. Am J Emerg Med 2004;22:6268.

9. Hofmeijer J, Kappele LJ, Algra A, et al. Surgical decompression for space-occupying cerebral infarction (the hemicraniectomy After Middle Cerebral Artery infarction with Life-threatening Edema Trial (Hamlet): a multicentre open, randomised trial. Neurology 2009;8:326-33

10. Vahedi K, Vicaut E, Mateo J, et al. Sequential-Design, Multicenter, Randomized, Controlled Trial of Early Decompressive Craniectomy in Malignant Middle Cerebral Artery Infarction (Decimal trial). Stroke 2016;38:2506-17.

11. Adams HP Jr, Adams RJ, Brott T, et al. Guidelines for the early management of patients with ischemic stroke: a scientific statement from the Stroke Council of the American Stroke Association. Stroke 2003;34:1056-83.

12. Hutchinson PJ, Corteen E, Czosynka M, et al. Decompressive craniectomy in traumatic brain injury. The randomized multicenter RESCUE ICP study. Acta Neurochir 2006;96:17-20.

13. Mass Al, Steyerberg EW, Butcher I, et al. Prognostic value of computerized tomography scan charecteristics in traumatic brain injury: results from IMPACT study. J Neurotrauma 2007;24:303-14.

14. Robertson SC, Lennarson P, Hasan DM, Traynelis VC. Clinical course and surgical management of massive cerebral infarction. Neurosurgery 2004;55:55-62.

15. Sauvigny T, Göttsche J, Vettorazzi E, Westphal M, Regelsgerber J. New radiological parameters predict clinical outcome after decompressive craniectomy. World Neurosurgery 2016;88(4):519-25.e1. 
16. Marmarou A, Lu J, Butcher I, et al. Prognostic value of Glasgow Coma Scale and pupil reactivity in traumatic brain injury assessed pre-hospital and enrollment: an IMPACT analysis. J Neurotrauma 2007;24:270-80.

17. Murray GD, Butcher I, McHugh GS, et al. Multivariable prognostic analysis in traumatic brain injury: results from the IMPACT study. J Neurotrauma 2007;24:329-37.

18. Tu PH, Liu ZH, Chuang CC, Yang TC, Wu CT, Lee ST. Postoperative midline shift as secondary screening for the long-term outcomes of surgical decompression of malignant middle cerebral artery infarcts. J Clin Neurosci 2012;19:661-4.

19. Kjimara M, Ikeda N, Suji, et al. An Autopsy case of traumatic middle cerebral artery occlusion. Nippon Hogaku Zassh 1993;47:134-6.
20. Juttler E, Schwab S, Schmiedek $P_{\text {, }}$ et al. Decompressive Surgery for the Treatment of Malignant Infarction of the Middle Cerebral Artery (Destiny), a randomized, controlled trial. Stroke 2007;38:2518-25.

21. Howard JL, Cipolle MD, Anderson M, et al. Outcome after decompressive craniectomy for the treatment of severe traumatic brain injury. J Trauma 2008;65:380-6.

22. Leeper CM, Kutcher M, Mckenna C, Billiar T, et al. Acute traumatic coagulopathy population: Definition, trend over time and outcomes. J Trauma Acute Care Surg 2016;81:3441.

23. Gupta G, Wadhwa C, Garg R, Dhaiya RS, Kaushal RK. Impact of coagulation profile on Outcome of Head Injury. J Clin Diagn Res 2016;10:PC04-6. 